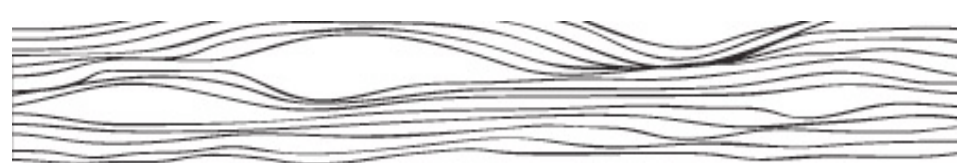

Public Space: The Journal of Law and Social Justice

\title{
A Feminist Critique of the Role of Medical Discourse in the Introduction of the Breastfeeding Amendment in the Anti-Discrimination Act 1977 NSW
}

\author{
Sallie McLean ${ }^{1}$
}

\begin{abstract}
Although breastfeeding in public space is protected under anti-discrimination laws throughout Australia, public breastfeeding remains an ambiguous and controversial issue. The NSW anti-discrimination amendment that expressly permits women to breastfeed in public was introduced using a decidedly medical discourse. Public breastfeeding was legitimised by recourse to the nutritional and economical advantage of breastfeeding. This rationale effectively disengages breastfeeding from the paradigm of women's rights, and leaves the act of breastfeeding itself open to substitution. A feminist jurisprudential analysis of the legitimising arguments behind the amendment illustrates how the focus on medical and economical concerns obscures the role that nationhood, capital and cultural practice play in denigrating breastfeeding as a distinctly female practice.
\end{abstract}

\section{Introduction}

'...lactating breasts when they are taken outside of the home are capable of disrupting the borders of morality, discretion, taste and politics; in short breasts are capable of transforming legislation, citizenship and cities themselves. ${ }^{2}$

\footnotetext{
${ }^{1}$ Final year honours student LLB Laws/Social Inquiry at the University of Technology, Sydney. Many thanks to Samantha McLean, Karen Smith and Penny Crofts for their comments and direction.

Public Space: The Journal of Law and Social Justice (2008) Vol 2, Art 5 pp 1-29.
} 
Policies, regulations and behaviour that discriminate against women for breastfeeding ${ }^{3}$ infants in public are generally rendered unlawful by anti-discrimination laws in Australia. ${ }^{4}$ In NSW, the Anti Discrimination (Breastfeeding) Bill 2007 (the Bill) ${ }^{5}$ that explicitly states that discrimination on the basis of breastfeeding is unlawful ${ }^{6}$ was introduced to amend the Anti-Discrimination Act 1977 (the Amendment). The primary rationale behind the Amendment was that breastfeeding is the optimum way to provide nutrition to an infant and will produce healthier children. The Amendment was designed to remove social barriers to breastfeeding in order to improve breastfeeding rates by extending the period of time for which infants are breastfed. A key consideration was the effect that continuation of low breastfeeding rates is likely to have on NSW health and economic systems into the future. ${ }^{7}$ This paper argues that framing the Amendment according to exclusively medical concerns is problematic. A medical rationale does provide authoritative justification for the legislative change, but scientific medical knowledge can change over time. ${ }^{8}$ In principle it leaves room for 'better' medical

\footnotetext{
${ }^{2}$ A Bartlett 'Scandalous Practices and Political Performances: breastfeeding in the city' (2002) 16(1) Continuum: Journal of Media and Cultural Studies 111.

${ }^{3}$ The Sex Discrimination Act 1977 (Cth) s 5(1A) defines breastfeeding as including the act of expressing milk. This paper recognizes that not all mothers are embodied as breastfeeding mothers such as nonbreastfeeding mothers, adoptive mothers and lesbian mothers who are not the biological mother. ${ }^{4}$ The Commonwealth and the following States and Territories have created legislation that explicitly renders discrimination on the grounds of breastfeeding unlawful: Sexual Discrimination Act 1977 (Cth) s5(1A); Equal Opportunity Act 1995 (VIC) s6(ab); Anti-Discrimination Act 1991 (Q1d) s7(e); Northern Territory Anti-Discrimination Act 1996 (NT) s19(h); and Tasmania Anti-Discrimination Act 1998 (TAS) s16(h).

${ }^{5}$ Assented on 1 November, 2007.

${ }^{6}$ The Anti-Discrimination Act 1977 NSW s24(1C) states that breastfeeding is a characteristic that appertains generally to women and includes the act of expressing breast milk.

${ }^{7}$ B Robins 'Law boosts public breastfeeding rights' Sydney Morning Herald (Sydney), 4 September 2007, 5; New South Wales, Parliamentary Debates, Anti-Discrimination (Breastfeeding) Amendment Bill 2007, Second Reading, New South Wales Hansard, 24 October 2007.

${ }^{8}$ B Hausman 'Mothers Milk: Breastfeeding Controversies in American Culture' (2003) 198; B Spencer 'The milk of human-kindness: from a short (personal) history of the bra and its contents' (2004) 19(45) Australian Feminist Studies 319.
}

Public Space: The Journal of Law and Social Justice (2008) Vol 2, Art 5 pp 1-29. 
alternatives to replace breastfeeding or breast milk as a source of nutrition. ${ }^{9}$ While not explicit in the language of the legislation, the health-oriented assumptions that underlie the Amendment denote the protected act to be the administering of breast milk, not breastfeeding per se.

Locating an anti-discrimination law to protect women against breastfeeding discrimination within a consequentialist health discourse and outside of a rights paradigm opens the rationale behind the Amendment to feminist jurisprudential analysis. ${ }^{10}$ Under such analysis, the medicalised health discourse is shown to allow for the ongoing construction of women's breasts as exclusively sexual, not maternal, objects, ${ }^{11}$ and conceals the role that capital, ${ }^{12}$ nationhood $^{13}$ and constructions of maternity ${ }^{14}$ play in devaluing breastfeeding as a woman's right.

\section{The Legislative Framework: Australian Laws and Breastfeeding}

Sexual discrimination laws have been instituted throughout Australia primarily to protect women ${ }^{15}$ against regulations, policy and behaviour that may otherwise exclude them from

\footnotetext{
${ }^{9}$ L Blum 'Mothers, Babies and Breastfeeding in Late Capitalist America: The Shifting Contexts of Feminist Theory' (1993) 19(28) Feminist Studies 8.

${ }^{10} \mathrm{C}$ Silberstein Shdaimah 'Why Breastfeeding is (Also) a Legal Issue' (1999) 10(2) Hastings Women's Law Journal 412.

${ }^{11}$ F Chatard Carpenter '(L)activists and Latté's: Breastfeeding Advocacy as Domestic Performance' (2006) 16(3) Women and Performance: a journal of feminist theory 352; CA Stearns 'Breastfeeding and the Good Maternal Body' (1999) 13(3) Gender and Society 309; IM Young On Female Body Experience: 'Throwing Like a Girl' and Other Essays (2005) 76.

${ }^{12}$ Blum, above n 9, 4; P Van Esterik 'The Politics of Breastfeeding: An Advocacy Perspective' in P StuartMacadam and KA Dettwyler (eds) Breastfeeding Biocultural Perspectives (1995) 158.

${ }^{13}$ F Giles 'Relational and Strange: a preliminary foray into a project to queer breastfeeding' (2004) 19(45) Australian Feminist Studies 304; C Kevin 'Maternity and Freedom: Australian Feminist Encounters with the Reproductive Body’ (2005) 20(46) Australian Feminist Studies 3; Van Esterik in Hausman, above n 8 , 219.

${ }^{14}$ Stearns, above n 11.

${ }^{15}$ The Sex Discrimination Act 1984 (Cth) s 3 states that the objects of the Act are: 'a) to give effect to certain provisions of the Convention on the Elimination of All Forms of Discrimination Against Women...'
}

Public Space: The Journal of Law and Social Justice (2008) Vol 2, Art 5 pp 1-29. 
participating in elements of public life. ${ }^{16}$ The Commonwealth Parliament enacted the Sex Discrimination Act 1984 (SDA), which explicitly named sexual discrimination as a form of actionable wrong. ${ }^{17}$ Due to jurisdictional restrictions of the Commonwealth ${ }^{18}$ and the corresponding requirement to cover all areas of public life, States and Territories mirrored sexual discrimination provisions in their Anti-Discrimination or Equal Opportunity Acts. ${ }^{19}$ In essence, sexual discrimination laws render it expressly unlawful to discriminate against persons on the basis of their gender.

The introduction of the $S D A$ was a landmark for women's rights. In 1984, it became unlawful for a person (the discriminator) to directly discriminate against another (the aggrieved) on the grounds of gender by treating the aggrieved less favourably than a person of the opposite sex due to the aggrieved's sex or a characteristic that appertains generally or is imputed towards a person of that sex. ${ }^{20}$ Direct sexual discrimination could also occur on the grounds of pregnancy or potential pregnancy. ${ }^{21}$ Indirect discrimination, where a condition or requirement is imposed (or proposed to be imposed) which in effect will discriminate against a person because of their sex, was also identified as unlawful. ${ }^{22}$

Commonwealth sexual discrimination laws also protect persons on the ground of marital status (s 6); pregnancy and potential pregnancy (s 7); and family responsibilities (s 7A).

${ }^{16} \mathrm{G}$ Mason and A Chapman 'Defining Sexual Harassment: A History of the Commonwealth Legislation and its Critiques' (2003) 31 Federal Law Review195.

${ }^{17}$ Sex Discrimination Act 1984 (Cth) s 5.

${ }^{18}$ Sex Discrimination Act (Cth) 1984 s 3(b) covers sexual discrimination on the ground of sex, marital status, pregnancy or potential pregnancy in the 'areas of work, accommodation, education, the provision of goods, facilities and services, the disposal of land, the activities of clubs and the administration of Commonwealth laws and programs'.

${ }^{19}$ Equal Opportunity Act 1995 (Vic); Anti-Discrimination Act 1991 (Q1d); Australian Capital Territory Discrimination Act 1991 (ACT); Northern Territory Anti-Discrimination Act 1996 (NT); Western Australia Equal Opportunity Act 1984 (WA); South Australian Equal Opportunity Act 1984 (SA) and Tasmania AntiDiscrimination Act 1998 (TAS).

${ }^{20}$ Sex Discrimination Act 1984 (Cth) ss 5(1)(a), (1)(b), (1)(c).

${ }^{21}$ Sex Discrimination Act 1984 (Cth) s 7.

${ }^{22}$ Sex Discrimination Act 1984 (Cth) ss 5(2), 7(2).

Public Space: The Journal of Law and Social Justice (2008) Vol 2, Art 5 pp 1-29. 
The introduction of the SDA meant that women who experienced discrimination had access to lawful redress, but this did not necessarily curb culturally ingrained policies of discrimination. In 1998, over seventeen percent of all complaints made to Human Rights and Equal Opportunity Commission (HREOC) were due to sexual discrimination on the grounds of pregnancy in the work place. ${ }^{23}$ Twenty-five percent of complaints about pregnancy related incidents were derived from indirect discrimination. ${ }^{24}$ This figure evidenced that the $S D A$ was not providing the anticipated protection for women in the workplace and prompted the then Attorney General ${ }^{25}$ to commission HREOC to inquire specifically into discriminatory practices occurring between employers and pregnant women. ${ }^{26}$ The resulting 1999 report, Pregnant and Productive: it's a right not a privilege to work while pregnant, had forty-six recommendations designed to strengthen the objective of the $S D A$ in regards to pregnancy and employment. One of these was that breastfeeding be specified as a separate ground of unlawful discrimination. ${ }^{27}$ Although breastfeeding issues were outside of the terms of reference for the report, the authors of the report stated that they were compelled to include recommendations on 'postpregnancy issues' because they were found to be central to issues of sex discrimination. ${ }^{28}$

It took three years for the Federal Government to respond to the HREOC report. The Sex Discrimination Amendment (Pregnancy and Work) Bill 2002 partially adopted three of

\footnotetext{
${ }^{23}$ Human Rights and Equal Opportunity Commission 'Pregnant and Productive: It's a right not a privilege to work while pregnant' (1999) 1.7; HREOC was legally constituted under s 48 of the Sex Discrimination Act 1984 (Cth).

${ }^{24}$ HREOC, above n 23, 4.44 .

${ }^{25}$ Daryl Williams.

${ }^{26}$ HREOC, above n 23, Terms of Reference vi.

${ }^{27}$ HREOC, above n 23, 14.1 .

${ }^{28}$ HREOC, above n 23, 14.1, 14.6; Sex Discrimination Amendment (Pregnancy and Work) Bill 2002 (Cth).

Public Space: The Journal of Law and Social Justice (2008) Vol 2, Art 5 pp 1-29. 
the forty-six recommendations ${ }^{29}$. One of the amendments included a clarification of $\mathrm{s} 5$ of the $S D A$. The law was not changed; instead a clarification that discrimination against a breastfeeding woman is a form of discrimination because breastfeeding is a characteristic that appertains generally to women was instituted. ${ }^{30}$ The delay and nominal response was heavily criticized in parliamentary debate. The strongest criticisms suggested that the amendment 'trivialize[d] the issues concerning pregnancy and breastfeeding in the labour force and in the community ${ }^{31}$ and, in essence, only clarified existing legislation that HREOC and the government had found in the first place to be inadequate to properly protect women. $^{32}$

\section{The Health of the State, the Law and Breastfeeding Rights}

In 2007, NSW parliament proposed to mirror the SDA amendment in s 24 of the AntiDiscrimination Act $1977^{33}$ (ADA) with the Anti Discrimination (Breastfeeding) Amendment Bill 2007 (the Bill). In September 2007, the Sydney Morning Herald published an article that presented the rationale of the proposed bill. ${ }^{34}$ The article points to 'women's organisations' claim that breastfeeding mothers are regularly asked to leave public premises when breastfeeding, despite the current legislative regime. The article cites medical professionals who assert that half of all babies in Australia are weaned off breastfeeding by six months, which is considered by health authorities to be too early.

\footnotetext{
${ }^{29}$ The Sex Discrimination Amendment (Pregnancy and Work) Bill 2002 (Cth) also operated to amend s 27 of the $S D A$, which clarified issues on potential employers asking about future pregnancy plans.

${ }^{30}$ Sex Discrimination Amendment (Pregnancy and Work) Bill 2002 (Cth) 3.

${ }^{31}$ Commonwealth, Parliamentary Debates, Senate, 8 September 2003, 14359, (Gavin Marshall).

${ }^{32}$ Commonwealth, Parliamentary Debates, Senate, 8 September 2003, 14362-3 (Kerry Nettle); 14368 (Patricia Crossin).

${ }^{33}$ Anti-Discrimination Act 1977 (NSW) unlawful sexual discrimination provisions operate over work, education, provisions of goods and services (including in restaurants and cafes), provision of accommodation, and in registered clubs.

${ }^{34}$ Robins, above $\mathrm{n} 7,5$.

Public Space: The Journal of Law and Social Justice (2008) Vol 2, Art 5 pp 1-29.
} 
Early weaning is said to contribute to health problems such as cot death, allergies, diabetes and obesity, which contributes to both a drain on public health services and parental absenteeism from work. A connection is then implicitly drawn between the lack of perceived lawful retaliation women have against forced removal from a public premise for breastfeeding and a general decrease in the length of time that women breastfeed for. The new law is thus set to encourage mothers to continue breastfeeding both publicly and in the workplace, which should 'ensure that children in NSW are given the best possible start in life. ${ }^{35}$

The contribution breastfeeding makes to public health and the economy is the dominant discourse in which government and legislators frame breastfeeding rights. The link drawn by the article between a clarification of anti-discrimination laws and a positive impact on the health of the community was reissued throughout the second reading speech of the Bill in NSW Parliament. This framework was typified in a statement given by parliamentarian Helen Westwood, who agreed with her colleagues ${ }^{36}$ when she stated:

Australian women do not breastfeed at rates jointly recommended by the World Health Organization and UNICEF. Protecting women from discrimination because they choose to breastfeed is one strategy to

\footnotetext{
${ }^{35}$ Robins, above n 7, 5: Robins quotes NSW Premier Mr Iemma.

${ }^{36}$ New South Wales, Parliamentary Debates, Legislative Council, 24 October 2007, 3138: Other examples include a further comment from Helen Westwood: 'It is very important that we as a Government do everything we can to support breastfeeding mothers to ensure that infants are breastfed for as long as possible. There are great health benefits of breastfeeding and they are widely known...'; and support from Robyn Parker: 'As an enthusiastic supporter of breastfeeding I am encouraged to hear that a greater number of women are now engaging in that activity, but this Government could do a lot more to promote the scientific benefits and the long-term and short-term health benefits of breastfeeding. The entire community should be given information about the best nutrition and health and women should be given information about the advantages of breastfeeding.' .
}

Public Space: The Journal of Law and Social Justice (2008) Vol 2, Art 5 pp 1-29. 
achieve better health and economic outcomes for Australia... There is now considerable evidence to suggest that increasing levels of breastfeeding in the Australian community will have a significant positive impact on the health of our community, and hence its productivity. Proscribing discrimination on the ground of breastfeeding will ensure that women who choose to breastfeed are protected from any discriminatory conduct that may impact on that choice.

Throughout parliamentary debate, any attempts to align the Bill with women's rights were immediately qualified by the 'real' need to increase the broader health benefits of breastfeeding. ${ }^{37}$ Parliamentarian Marie Ficarra noted that the Bill will protect breastfeeding women from 'harassment, intimidation, ridicule or just plain social stupidity' and that the amendment will end unfair restrictions on women's postnatal movements. ${ }^{38}$ This statement was immediately followed by the qualification that '[a]n important reason for encouraging breastfeeding is that it protects the child, particularly in the first 6 to 12 months of its life...' Similarly, the Legislative Review Committee's published findings on the Bill noted that the proposed amendment provides protection and redress for women who have had their 'personal rights and liberties' unduly trespassed because they were treated 'less favourably' for breastfeeding. This statement was supported by evidence about the 'increasing...benefits for the health of the

\footnotetext{
${ }^{37}$ New South Wales, Parliamentary Debates, Legislative Council, 26 September 2007, 2342 (Barry Collier): This sentiment was echoed in this Agreement in Principle Speech.

${ }^{38}$ New South Wales, Parliamentary Debates, Legislative Council, 24 October 2007, 3138

Public Space: The Journal of Law and Social Justice (2008) Vol 2, Art 5 pp 1-29. 
community' breastfeeding will provide. ${ }^{39}$ This rationale is not limited to parliamentary media releases, papers and debates. Breastfeeding advocacy groups, ${ }^{40}$ NSW Health collateral $^{41}$ and information service providers also rationalise breastfeeding rights within a medical framework. In a report on breastfeeding in Australia the Australian Bureau of Statistics states breastfeeding is an important issue to the community because of its potential to increase public health by increasing the baby's resistance to infection and disease. ${ }^{42}$ Women's health concerns are also canvassed and only one sentence is allocated to the psychological benefits of breastfeeding between a mother and infant. The issue of breastfeeding as a woman's right is not considered.

\section{Medical Knowledge, Legal Interpretation and the Operation of the Amendment}

The narrow focus of legislators and the law on the health benefits of breastfeeding generates particular narratives about breastfeeding that privileges medical knowledge over women's experiences. Breastfeeding is supported at law because it serves a nutritional function that helps preserve the economic and physical health of the state. ${ }^{43}$ The 'rational' and attainable benefits of breastfeeding are given primacy over other possible breastfeeding narratives such as naturalism and women's rights. ${ }^{44}$ The law endorses a consequentialist ethic ${ }^{45}$ under which breastfeeding is advocated because it is

\footnotetext{
${ }^{39}$ Legislation Review Committee, Parliament of NSW, Legislation Review Digest No 3 (2007) 3.

${ }^{40} \mathrm{M}$ Grove, 'Public breastfeeding protected by the law' (2007)

http:/www.6minutes.com.au/articles/z1/view.asp?id=74703 October 2007: Margaret Grove, the National President of the Australian Breastfeeding Association, welcomed the Bill: 'This is a great first step which further highlights breastfeeding as a vital health issue.'

${ }^{41}$ New South Wales Department of Health 'Having a Baby' (2006) NSW Government, Families First, 126.

${ }^{42}$ Australian Bureau of Statistics (2001) 'Breastfeeding in Australia' 4810.0.55.001, Australia, 2001.

${ }^{43}$ KA Dettwyler 'Beauty and the Breast: The Cultural Context of Breastfeeding in the United States' in P Stuart-Macadam and KA Dettwyler (eds) Breastfeeding Biocultural Perspectives (1995), 174.

${ }^{44}$ Bartlett, above n 2, 116.

${ }^{45}$ MDA Freeman Lloyds Introduction to Jurisprudence $\left(7^{\text {th }}\right.$ ed, 2001) 201: Also referred to as a Utilitarianist ethic.
}

Public Space: The Journal of Law and Social Justice (2008) Vol 2, Art 5 pp 1-29. 
perceived to have positive health and medical outcomes for the greater community. This reinstitutes biomedical understandings of the body as the only legitimate approach to take when legislating on the body and its processes. ${ }^{46}$ By operating within this framework, the law lays the foundation for artificial alternatives of equal nutritional value to be held superior or more appropriate than breast milk, and further divorces the act of breastfeeding from protection under the spectrum of women's rights. ${ }^{47}$

Within mainstream Australian culture, medical and scientific knowledge has patent currency. While medical knowledge has authority to determine laws and regulations, ${ }^{48}$ the content and context of that knowledge can change over time. ${ }^{49}$ In 2007, breastfeeding is understood to provide the ultimate good health to an infant. ${ }^{50}$ During the 1970s, the medical community endorsed chemically produced infant formula as the optimum way to ensure infant health. ${ }^{51}$ It is a testament to the power and authority of medical discourse and practice that during this time less than one in five Australian babies were breastfed. ${ }^{52}$ Feminist and cultural studies scholar Bernice Hausman notes that 'since the 1950's breastfeeding promotion has increasingly depended on the discourses of scientific medicine. ${ }^{53}$ As long as medical discourse remains heavily influential over maternity practices, the current positive status of breastfeeding remains open to challenge. A pertinent example is seen in two recent Australian studies on breastfeeding and allergies.

\footnotetext{
${ }^{46}$ Hausman, above n 8, 198.

${ }^{47}$ Dettwyler, above n 43, 189.

${ }^{48}$ For example, anti-smoking legislation.

${ }^{49}$ Giles, above n 13, 301.

${ }^{50}$ See the Australian Breastfeeding Association website at $<$ http://www.6minutes.com.au/articles/z1/view.asp?id=74703>.

${ }^{51}$ B Spencer 'The milk of human-kindness: from a short (personal) history of the bra and its contents' (2004) 19(45) Australian Feminist Studies 319: This is still so in the US.

${ }_{52}^{5}$ Ibid.

${ }^{53}$ Giles, above n 13, 304.

Public Space: The Journal of Law and Social Justice (2008) Vol 2, Art 5 pp 1-29.
} 
At the same time that the Amendment was going through Parliament, studies released by the Children's Hospital in Westmead and the University of Melbourne found that women with allergies who breastfed their children for longer than 6 months offered no protection to the infant and indeed increased the likelihood that the infant will develop allergies later in life. ${ }^{54}$ The research was used to support a call for the current blanket recommendations on breastfeeding to be reconsidered. ${ }^{55}$

The way that legislation is framed can impact the way that certain provisions are understood to operate by the courts. Under the current legislative regime discriminating against women for breastfeeding is unlawful and women who have been disadvantaged by discrimination are granted access to a remedy. When viewed in isolation, the amendment ostensibly meets a legal objective of protection and redress. ${ }^{56}$ If the goal is to create conditions in which every woman has the choice to breastfeed in any environment, then it can be perceived that an important step is satisfied by the Amendment. However, laws are not simply obeyed by courts; they are interpreted, construed and then applied by jurists. Through this process, the purpose behind the amendment can influence the way the law is interpreted and applied. ${ }^{57}$ Under the Interpretation Act $1987,{ }^{58}$ when there is contention about the meaning of the statutory words, the courts are directed to form a

\footnotetext{
54 'Breastfeeding worsens asthma, allergies in children' 1 May 2007, http://www.theaustralian.news.com.au/story/0,20867,21652457-2702,00.html, October 2007; H Ife

'Breastfeeding may pass on allergies' 1 October 2007, http://www.news.com.au/heraldsun/story/0,21985,22508706-2862,00.html October 2007; M Matheson

'Breastfeeding increases long term allergy risks in those with a family history, says University of Melbourne study' (Press Release, 1 October 2007), http://uninews.unimelb.edu.au/articleid_4660.html October 2007.

${ }_{55}^{55}$ Matheson, above n 54.

${ }^{56}$ Freeman, above $\mathrm{n} 45,200$ : This construction of argument is grounded in positivist philosophy that rejects natural law rights and looks instead towards the content of the law.

${ }^{57} \mathrm{This}$ is a general observation. The author has not conducted a review of how the purposeful approach has been received in specific cases of discrimination.

${ }^{58}$ Interpretation Act 1997 (NSW) s 33.
}

Public Space: The Journal of Law and Social Justice (2008) Vol 2, Art 5 pp 1-29. 
'construction that would promote the purpose or object underlying the Act or statutory rule'. This is especially applicable when the courts construe beneficial legislation designed to protect human rights such as the $A D A$ and the $S D A$. Here, the '[c]ourt has a special responsibility to take account of and give effect to the purposes and objects of the legislation. ${ }^{59}$ It is common for judges when ascertaining purpose to refer to the second reading speech, which in this case clearly states that the purpose of the Amendment is to promote and defend nutritional infant feeding practices, with an emphasis on the importance of public health and the role of long-term breastfeeding. In a framework that privileges the health model, it is open for the courts to find, in certain circumstances, that expressing milk to be fed to the infant from a bottle would still fit within the purpose of the Act. ${ }^{60}$ Under the Amendment, the law may have created conditions that make breastfeeding outside the home possible, but this does not translate to breastfeeding per se being a valued and protected practice in society. Without an in-principle approach that accepts breastfeeding at work and in public places, there is a possibility that women will not be able to do more than argue for breast pumping breaks at work. ${ }^{61}$

An interpretation in favour of artificial feeding is possible in NSW because the law 'ignores or never knew the exigencies of breastfeeding as an embodied practice. ${ }^{62}$ Classifying breastfeeding as an issue of public health does not allow for breastfeeding to be anything more than a nutritional decision even though it involves the enactment of a

\footnotetext{
${ }^{59}$ Howe v QANTAS Airways Ltd [2004] FMCA 242.

${ }^{60}$ Blum, above $\mathrm{n} 9,8$.

${ }^{61}$ B Hausman 'The Feminist Politics of Breastfeeding' (2004) 19(45) Australian Feminist Studies 282: Hausman sites this specific hypothetical.

${ }^{62}$ Ibid, 281.

Public Space: The Journal of Law and Social Justice (2008) Vol 2, Art 5 pp 1-29.
} 
woman's body in a deeply personal way. ${ }^{63}$ The medical discourse that frames the Amendment reconstitutes and reissues a complex personal human interaction as a straightforward public health concern. This diminishes the experience and role of women who choose to breastfeed and represents a problematic simplification of the argument for breastfeeding rights. As noted by anthropologist Katherine A. Dettwyler ' $[\mathrm{t}] \mathrm{o}$ argue that breastfeeding has only one legitimate function, a nutritional one, is analogous to insisting that sexual intercourse has only one legitimate function, a procreative one. ${ }^{64}$

\section{Breastfeeding and the Public Domain}

A unifying principle of the early feminist movement was the belief that what happened behind 'closed doors' need be brought out into the public. ${ }^{65}$ The requirement that 'private' issues that predominately affected women be legislated upon was echoed in the feminist mantra that the 'personal is political' ${ }^{66}$ It was this conflation of private and public spheres, combined with women's broader contribution to public and economic life that led to the call for breastfeeding in public to be lawful. ${ }^{67}$ Mothers with small children often participate in work life and are likely to attend public places like parks, shopping centres and restaurants. The Amendment means that women outside of the home will be able to breastfeed their infants without fear of being excluded from that public place. This does not mean that women have gained the right to breastfeed in public; rather, it is

\footnotetext{
${ }^{63}$ Silberstein Shdaimah, above n 10, 442

${ }^{64}$ Dettwyler, above n 43, 207.

${ }^{65}$ A Heywood Politics (1997) 150: 'second wave feminism' was defined by its call for structural change that needed to start within the domestic sphere. Cf KM Reiger Our Bodies, Our Babies: The Forgotten Women's Movement (2001) 160: Reiger charts the ambivalent relationship between mothers' support networks such as the NMAA (ABA) and feminist politics. The relationship was mutually antagonistic but it is undecided if they were separate movements altogether, or distinct aspects of the same historical push for women's rights.

${ }^{66}$ Chatard Carpenter, above n 11, 348.

${ }^{67}$ Bartlett, above n 2, 112, 115: notes 'Literally staying 'at home' with a baby now seems unusual.'; P Carter Feminism, Breasts and Breastfeeding (1995) 107.
} 
infants that have gained the right to be fed in public. In 1997, a Melbourne woman was asked to leave the food court of a casino for breastfeeding her infant. She was told by the staff that members of the public had complained about the act being 'offensive and distasteful. $^{.68}$ In 1999, the Queensland Young Liberals proposed that women breastfeeding outside designated areas be fined on the spot. This archaic proposition was supported by the One Nation party, which was experiencing growing support at the time ${ }^{69}$ Both Queensland and Victoria had anti-discrimination laws in place.

Strong anti-breastfeeding sentiment in public or work domains need not be isolated to officious staff or alarmist right wing parties. An acute example of how breastfeeding can exclude women from public life occurred in 2003 when parliamentarian Kirstie Marshal was asked to leave the Victorian Senate when breastfeeding her ten day old infant. ${ }^{70}$ While parliament held that the attendance of a non-parliamentary member - that is the baby - breached the 'stranger in the house' conventions, it is more likely that the overt display of womanhood was too confronting for the realm of parliament house. Breastfeeding in parliament brought 'the most private part of the public sphere into the most public part of the public [which was] a rejection of and a challenge to the validity of boundaries. ${ }^{, 71}$ It is significant to note that the amendments to the $A D A$ will not change the convention of 'stranger in the house' in parliament. Women can still be lawfully discriminated against for breastfeeding in their workplace if that workplace is parliament.

\footnotetext{
${ }^{68}$ Bartlett, above n 2, 115-116.

${ }^{69}$ Bartlett, above n 2, 116 .

${ }^{70}$ R Shaw 'The Virtues of Cross-nursing and the 'Yuk Factor' (2004) 19(45) Australian Feminist Studies 287.

${ }^{71}$ Imray and Middleton (1983) in Carter (1995) above n 67, 107.

Public Space: The Journal of Law and Social Justice (2008) Vol 2, Art 5 pp 1-29.
} 
Legislation on breastfeeding is a significant component of the political debate about the status and role of women. ${ }^{72}$ While the current amendments are claimed to protect women, it is difficult to reconcile messages about the health benefits of breastfeeding and the undercurrent that it may not be appropriate to breastfeed publicly in certain situations with a message of greater emancipation for women. The controversy surrounding breastfeeding in public shows that women's bodies still have an uncertain status in public space. ${ }^{73}$ On this point, feminist Iris Marion Young asserts that the explicit and implicit understandings that restrict women from breastfeeding in public are indicative of the fact that 'women are not as free as they ought to be. ${ }^{74}$

\section{Capitalism, Nation Building and Breastfeeding}

The rationale of the Amendment aligns with key tenets of capitalism, specifically, continuing wealth generation and full participation in economic life. It is proposed that under the Amendment, children of the state will grow up to be healthier (more productive); parents will require less sick leave to watch over their children and, as a corollary, be able to spend more time in the work force; and women will be enabled to breastfeed at their place of employment, which encourages them to return to work shortly after birth. ${ }^{75}$ In this regard, it is clear that the function of the Amendment is to contribute to the stabilisation and ongoing economic prosperity of the state. In Australia, capitalism and women's rights have often been implicated in discourses of nation building. ${ }^{76}$

\footnotetext{
${ }^{72}$ Carter, above n 67.

${ }^{73}$ Hausman, above n 61, 274.

${ }^{74}$ Young, above n 11, 3.

${ }^{75}$ New South Wales, Parliamentary Debates, Legislative Council, 24 October 2007, 3138.

${ }^{76}$ Kevin, above n 13: This paper does not review the cultural implications of breastfeeding on indigenous Australia - for an investigation into that area see A Bartlett 'Black Breasts, White Milk? Ways of Constructing Breastfeeding and Race in Australia' (2004) 19(45) Australian Feminist Studies 341.
}

Public Space: The Journal of Law and Social Justice (2008) Vol 2, Art 5 pp 1-29. 
Catherine Kevin's article 'Maternity and Freedom: Australian Feminist Encounters with the Reproductive Body,77 explores the relationship between maternity and female citizenship that has been cultivated by Australian governance. While Kevin focuses on the role that fertility and reproduction play in constructions of female citizenship, she notes that the choices that women make about their maternal body and practices are still presented as issues of national or state concern. ${ }^{78}$ This is illustrated by the intensity of recent parliamentary debate about access to abortion and the abortion drug RU42. The notion that women's bodies continue to be produced as both obstacles to and insurers of the future of the nation is central in the discourse of maternal rights. ${ }^{79}$ When breastfeeding is framed as a public good, it is opened to public comment and a sense of public ownership over a woman's maternal behaviour. ${ }^{80}$ That the legislators approached the Amendment in this way illustrates that the state believes it has a legitimate interest and right to influence a mother's private decision about how to feed her infant. ${ }^{81}$ The extent of this interest would be significantly minimized if breastfeeding was situated within a rights discourse instead of framed as a necessary contribution to the state. Once located as a right, ownership over the act of breastfeeding is handed back to women and leaves women free to legitimately choose whether or not to breastfeed based on their own ideological or biological reasoning.

\footnotetext{
${ }^{77}$ Kevin, above n 13 .

${ }^{78}$ Kevin, above n 13, 9: The connection between maternity and nationhood was made even more explicit by recent comments of the then Commonwealth Treasurer Peter Costello who stated that women should have 'one [a child] for them, one for their husband and one for the country.' (Kevin also deconstructs this statement to show that maternity is valid and legitimized by the state when the mother is Australian (white) and married.)

${ }^{79}$ Kevin, above n 13,3 .

${ }^{80}$ Stearns, above $\mathrm{n} 11,308$.

${ }^{81}$ Giles, above n 13, 304; Hausman, above n 8, 219.
}

Public Space: The Journal of Law and Social Justice (2008) Vol 2, Art 5 pp 1-29. 
The particularities of the relationship between capitalism, nationalism and maternity in Australia are not necessarily replicated in other western democratic societies. In the US, enterprise capitalism, in which the 'invisible hand' of the market is ultimately supreme, has nurtured a different type of relationship between capital and breastfeeding. ${ }^{82}$ When the only competition for a multi-billion dollar industry is the not-for-profit breast, providing nutrition to infants presents as a market opportunity. Through the combined efforts of the medical profession, legislators and corporate producers of breast milk substitutes, breastfeeding has been presented in the US as an unnecessary and even shameful practice. ${ }^{83}$ Only fifty percent of American mothers breastfeed at birth, ${ }^{84}$ and breastfeeding is generally viewed with suspicion by US authorities. An extreme example comes from Texas where a husband and wife were arrested under child pornography charges for taking a photo of the mother breastfeeding her infant. ${ }^{85}$ Other examples are more commonplace and include breastfeeding women being asked to leave establishments, or to stop breastfeeding while travelling on a commercial airplane. ${ }^{86}$ These policies have met some opposition ${ }^{87}$, but producers of formula still sell over four billion dollars worth of product per annum. ${ }^{88}$ These corporations also supply a large

\footnotetext{
${ }^{82}$ Blum, above n 9; Van Esterik, above n 11.

${ }^{83}$ Blum, above n 9, 4; Van Esterik, above n 11, 158: the authors refer to this coupling as an 'unholy alliance.'

${ }^{84}$ SI Olsen 'Out of the Mouths of Babes: No Mother's Milk for U.S. Children: The Law and Breastfeeding' (1996) 19 Hamline Law Review 274.

${ }^{85}$ Giles, above n 13, 305.

${ }^{86}$ Chatard Carpenter, above $\mathrm{n} 11$.

${ }^{87}$ In the US there are many breastfeeding advocacy groups and women 'lactivists' who protest against corporations with unfriendly breastfeeding policies; Olsen, above $n 92$ and Silberstein Shdaimah, above $n$ 14 note that in New York breastfeeding has been declared a civil right and the Federal Court has viewed breastfeeding as a constitutional right; but breastfeeding rights remain subordinate to the rights of business policy. For a thorough overview of the rise of capitalist milk production and the corresponding resistance see Van Esterik, above n 12; for a scathing review of the evils of the formula companies see N Baumslag and D Michels Milk, Money and Madness: The Culture and Politics of Breastfeeding (1995) Section III 'Breastmilk Economics - Shaping Corporate and Governmental Policies.'

${ }^{88}$ Blum, above n 9, 5.
}

Public Space: The Journal of Law and Social Justice (2008) Vol 2, Art 5 pp 1-29. 
portion of research grants into the topic area, produce marketing tools to be distributed to new mothers, finance hospitals, and consult in hospitals. ${ }^{89}$ In a country that promotes the 'invisible hand' of the marketplace, this form of activity has been permitted with very little legislative interference. ${ }^{90}$ The extent of involvement by corporate producers has led resistance groups to link the prevalence of direct and indirect formula advertising and promotion with low breastfeeding rates and women's negative perceptions of breastfeeding. ${ }^{91}$ The profitability of the formula marketplace and the vigorous marketing campaigns that collude with the medical profession to demote breastfeeding has resulted in a national environment where it is unusual for the mother to be the sole provider of nutrition to an infant. As noted by US feminist Linda Blum, this outcome is 'evidence of the power of corporate producers to efface the mother ${ }^{92}$ and of the incursion of capital relations into the reproductive sphere. ${ }^{93}$

\section{Cultural Feminism and Breastfeeding}

Breastfeeding is a female-specific activity that encompasses notions of the body, freedom and constraint. A feminist politic is implicitly tied to the act of breastfeeding because breastfeeding disrupts normative ideas about the function and aesthetic of the female body; ${ }^{94}$ deconstructs domestic borders $;{ }^{95}$ and resists commodification. That breastfeeding has been constructed as an economic and health issue, which ignores this feminist politic,

\footnotetext{
${ }^{89}$ Ibid.

${ }^{90}$ Blum, above n 9, 5; Van Esterik above n 12,151.

${ }^{91}$ Van Esterik, above n 12, 151.

${ }^{92}$ Blum, above n 9, 5 .

93 'Reproduction' in this sense refers to those embodied activities that are deemed unproductive and are situated outside of marketplace relations, but which are responsible for the re-production of the conditions of everyday life, such as breastfeeding or household domestic work.

${ }^{94}$ Stearns, above n $11,316$.

${ }^{95}$ Chatard Carpenter, above n $11,348$.

Public Space: The Journal of Law and Social Justice (2008) Vol 2, Art 5 pp 1-29.
} 
reveals "patriarchal structures of meaning" ${ }^{96}$ within the Amendment. Breastfeeding is a site for feminist analysis because 'much feminist reflection begins from the sociohistorical fact that women's bodily differences from men have grounded or served as excuses for structural inequities. ${ }^{97}$

Cultural feminism is a school of feminist thought that embraces women's differences from men. ${ }^{98}$ It recognizes that women are differently embodied than men, and that this impacts on their experience, decision making and prioritising. The most important and obvious difference is that women give birth and raise children. This focus on maternalism can be problematised because it essentialises gendered traits and universalizes the privileged experience of middle class white women. ${ }^{99}$ The form of maternalistic feminism advocated by culturalists is also in danger of perpetuating women's subordination by entrenching the notion that women are primarily mothers who should stay at home or be constrained by other features of maternalism. ${ }^{100}$ Romanticising what have historically been traits of subordination ignores the diversity of women's experiences and can be mobilized against the women's movement to support conservative agendas such as denying access to RU42 and supporting foetal rights. ${ }^{101}$

Cultural feminists do celebrate the same feminine traits that traditional culture has stereotypically used to justify the exclusion of women from public life, but there is a shift

\footnotetext{
${ }^{96}$ Stearns, above n 11, 308.

${ }^{97}$ Young, above $\mathrm{n} 11,4$.

${ }^{98}$ Defined by P Cain (1990) and R West (1988) 'Jurisprudence and Gender' in MDA Freeman Lloyds Introduction to Jurisprudence $\left(7^{\text {th }} \mathrm{Ed}, 2001\right)$.

${ }^{99}$ Cain, above n 98, 1154; Freeman, above n 98, 1134.

${ }^{100}$ Hausman, above n 65, 281.

${ }^{101}$ Blum, above $\mathrm{n} 9,2,3,7,8$ : Blum cites the dismantling of abortion rights and the increase of foetal rights as two corresponding conservative agendas possibly empowered by cultural feminism.
}

Public Space: The Journal of Law and Social Justice (2008) Vol 2, Art 5 pp 1-29. 
in emphasis from subordination to empowerment. ${ }^{102}$ Women's pregnant or maternal bodies are unique to women and should be celebrated for their 'female-ness. ${ }^{103}$ Cultural feminist Robin West contends that what underlies cultural feminism is the concept of woman's uniqueness - they have a connection to other human lives which men simply do not. They are not defined in relation to men but stand alone. ${ }^{104}$ That sense of connection 'entails a way of learning, a path of moral development, an aesthetic sense and a view of the world and of one's place in it that sharply contrasts with men's. ${ }^{105}$ Cultural feminism permits 'alternative economies of emotion ${ }^{, 106}$ to intersect with theories about the law and introduces the maternal body as a legitimate site for discussion. Maternal politics can then be used to push for rights in discrete female areas of concern, such as breastfeeding.

The legislation and policies of Australia and the US attempt to own or break the relationship of reproduction between a mother and an infant. In doing so, these policies discount that breastfeeding, as a private, intimate and embodied act, resists commodification and indeed lays challenge to capitalism and its liberalist foundation. Individualism and the autonomous subject are the "core principles of liberal ideology., 107 In a liberalist framework, human beings are seen as free, rational individuals who can make decisions within a free market. The notion of the neutral 'rational individual' is

\footnotetext{
${ }^{102}$ West, above n 98, 1160.

${ }^{103}$ Ibid, 1165 .

${ }^{104}$ Ibid, 1161: this observation stands in direct opposition to Catherine Mackinnon's assertion that feminist models that purport to celebrate difference rely on maleness as their standard and as such affirm male dominance: see CA MacKinnon 'Difference and Domination: On Sex Discrimination' in MDA Freeman Lloyds Introduction to Jurisprudence $\left(7^{\text {th }} \mathrm{ed}, 2001\right), 1175$.

105 Ibid, 1161.

${ }^{106}$ Hausman, above n 65, 281

${ }^{107}$ Heywood, above n 73, 41: J Locke 'the Second Treatise of Government' in J Locke Two Treatise of Government (1997), 183: Locke states that 'It is the government's sole function to protect and administer individual and market freedoms, including property rights and civil protection.'
}

Public Space: The Journal of Law and Social Justice (2008) Vol 2, Art 5 pp 1-29. 
ubiquitous at law and sets the standard for reasonable and legal behaviour. ${ }^{108}$ The law values human autonomy and gives primacy to individual action, which disregards the possibility that women's 'existential state is grounded in...physical, maternal connection to human life. ${ }^{109}$ Robin West argues that the maternal body lays challenge to the liberal autonomous subject, and, by deduction, the 'rational individual." ${ }^{110}$ The pregnant or breastfeeding female body, inextricably linked to the infant body reliant upon it for its survival, represents a physical and aesthetic challenge to the notion of the autonomous individual. The Rule of Law is inherently masculine because it does not value this intimacy - it only values autonomy. ${ }^{111}$ Maternity does not fit within the masculine constructs of liberalism, capitalism or the law. For West, before maternalism can be truly valued, notions of freedom and the law would have to structurally change to accommodate a more female understanding of being. ${ }^{112}$ The Amendment takes an important step towards recognising interdependence and intimacy between mother and child, but falls short at creating any real structural changes. In fact, the framing of rights inherent in the Amendment remains embedded in the rhetoric of capital, nationhood and individualism.

\section{Disgust and the Discreet Breast}

A cultural feminist critique of the Amendment reveals how the employment of a medical discourse in favour of a declaration of rights continues to deny the unique value of the

\footnotetext{
${ }^{108}$ The 'rational individual' has been criticized as a test of limited meaningful application because it embodies standards set by privileged white males.

${ }^{109}$ West above n 106, 1159: West also critiques the Critical Legal Studies (CLS) movement for taking a masculine position on the idea of separation: CLS acknowledges the state of separation but sees it as the cause of angst and desires to reform and unite with the community (1160).

${ }^{110}$ West above n 106, 1158-59.

${ }^{111}$ West above n 106, 1167.

${ }^{112}$ West above $\mathrm{n} 106,1174$.

Public Space: The Journal of Law and Social Justice (2008) Vol 2, Art 5 pp 1-29.
} 
female body. ${ }^{113}$ The use of a medical discourse means the law does not have to recognize the rights of women, or her maternal body. Instead, breastfeeding is confronting because it presents the public with both a sexualized organ and bodily excretion. In all other cases when these two areas come together in public they are grounds for offence. As long as the act of breastfeeding is not framed by the Amendment as a woman's right, it is likely to remain viewed in the same way. American social researcher, Corey Silberstein Shdaimah, ${ }^{114}$ found that people who oppose breastfeeding in public routinely compare it to sexual or defecatory acts. The clear message from breastfeeding detractors is that breastfeeding, like sex or defecation, may be natural but this does not mean it should be done in public. ${ }^{115}$ In 1998, a University of Adelaide study found that eighty-three percent of the community believed that bottle-feeding in public places was more acceptable than breastfeeding. ${ }^{116}$ This scholarship reveals how breastfeeding and breast milk are perceived as 'dirty' and not something to be ingested in company, ${ }^{117}$ and how nominal 'changes in the law do not guarantee changes in social practice.'118

The rationale of the Amendment is silent on the rights of women and the affirmation of the female body. This silence can be taken as an implicit validation of the current prevailing attitude that public breastfeeding, or being exposed to another person who is breastfeeding, may be as disgusting as public defecation. Legal theorist Martha

\footnotetext{
${ }^{113}$ Bartlett above n 2, 118 .

${ }^{114}$ Above $\mathrm{n} 14$.

${ }^{115}$ Silberstein Shdaimah above n 14, 412.

${ }^{116}$ McIntyre E (1998) 'Community prefers bottle feeding to breastfeeding in public' The University of Adelaide, Media Release, Monday $6^{\text {th }}$ July 1998: The research included 3,400 participants.

${ }^{117}$ Chatard Carpenter above n 11, 351; Shelton DM (1996) 'When Private Goes Public: Legal Protection for Women who Breastfeed in Public and at Work' Law and Inequality, Vol.14, 179-180.

${ }^{118}$ Olsen above n 92.

Public Space: The Journal of Law and Social Justice (2008) Vol 2, Art 5 pp 1-29.
} 
Nussbaum ${ }^{119}$ notes that powerful emotions of disgust are often the result of the discomfort people feel over having an animal body. ${ }^{120}$ The 'locus classicus' of projected disgust is towards the female body. ${ }^{121}$ The female body embodies many of the taboos surrounding sex and birth, and opponents of public breastfeeding seek to 'ward off something that is too physical, that partakes [in] too much secretions of the body. ${ }^{122}$ That breastfeeding in public is considered disgusting is a key reason why the Amendment needed to be introduced, yet is also why the presented advantages of breastfeeding steer away from the innate 'animal' naturalness of the act. Nussbaum asserts that disgust is a powerful socially constructed emotion that has been mobilized throughout time to exclude certain groups and persons from public life. Accordingly, even when the law's validation of disgust is not explicit that law should be treated critically. ${ }^{123}$

Inherent in the disgust of breastfeeding is the confusion it renders between a sexualized body part and a maternal act. On one hand, to sexualize a lactating breast is culturally taboo, while on the other, the sexual allure of breasts is a key reason why their exposure is considered offensive. These tensions may 'threaten the lateral, erotic male-female tie [to breasts] by invoking the generational tie in which eroticism is taboo, ${ }^{124}$ but women's behaviour in public remains primarily influenced by the male gaze. ${ }^{125}$ A 2002 Australian study found that members of the public believe that exposure of the breast while

\footnotetext{
${ }^{119}$ Nussbaum M Hiding from Humanity: Disgust, Shame and the Law, Chapter 2, 'Disgust and our Animal Bodies', (2004): this is not a detailed exploration of Nussbaum's theories, but a minor overview of Nussbaum's work on disgust as relevant to the topic area.

${ }^{120}$ Nussbaum above $\mathrm{n} 119,72,74$.

${ }^{121}$ Nussbaum above n 119, 111 .

${ }^{122}$ Nussbaum above n 119,113.

${ }^{123}$ Nussbaum above $\mathrm{n} 119,107$ : this statement was directed at great tragic events such as Nazi genocide, but it can equally apply to the micro-cosmos of breastfeeding women.

${ }^{124}$ Chatard Carpenter above $\mathrm{n} 11,352$.

${ }^{125}$ Bartlett above n 2, 117; Chatard Carpenter above n 11, 349; Stearns above n 11, 316.

Public Space: The Journal of Law and Social Justice (2008) Vol 2, Art 5 pp 1-29. 
breastfeeding an infant is an act likely to tempt sex fiends and degenerates. ${ }^{126}$ Likewise, American academic researcher Cindy Stearns ${ }^{127}$ found women who breastfeed in public are concerned that the act of breastfeeding may be misread as a sexual invitation. ${ }^{128}$ This concern has been realized in some detractors' responses, where women who breastfeed in public have been labelled 'exhibitionists' and 'tramps. ${ }^{129}$ The perception of breast milk and breastfeeding as dirty, sexual, or both is fostered by an inability to conceive the breasts as anything more than 'corporeal symbols of female sexuality. ${ }^{130}$ This means that for women to successfully breastfeed in public, breastfeeding must be carefully managed as 'though it were deviant behaviour, occurring within a potentially hostile environment. ${ }^{131}$

Breastfeeding in public is governed by the requirement of discreetness. This requirement is even supported by those groups and women who are proponents of breastfeeding rights. Stearn's study described how women uniformly highlighted the importance of discretion: not showing the breast, especially the nipple in public, is a valued skill. ${ }^{132}$ The Australian Breastfeeding Association website directs women to the most discreet public places to breastfeed. Women are advised to use 'baby care rooms' or changing rooms in women's clothing stores. If out with friends and families, Australian women are

\footnotetext{
${ }^{126}$ Bartlett above n 2, 117.

${ }^{127}$ Stearns above $\mathrm{n} 11,308,316$ : Stearns coined the phrased 'the good maternal body' which is descriptive of the desexualisation of the women's breast during breastfeeding and the corresponding, but incongruous, discreetness required by women to hide their breasts during lactation in public.

${ }^{128}$ Also see Carter above n 75, 219.

${ }^{129}$ Chatard Carpenter above n 11, 354 - 355: examples come from a forum about a US (L)activist group who held a mass breastfeeding sit in at Starbucks. Although this example is from the US, similar language can be found when traversing Australian online discussions about breastfeeding rights (see: http://blogs.theaustralian.news.com.au/yoursay/index.php/theaustralian/comments/is_breastfeeding_in_pub lic_a_mums_right/)

${ }^{130^{-}}$Chatard Carpenter above n $11,351$.

${ }^{131}$ Stearns above $\mathrm{n} 11,312$.

${ }^{132}$ Stearns above $n 11,312-313$.

Public Space: The Journal of Law and Social Justice (2008) Vol 2, Art 5 pp 1-29. 
told that 'it is easy to breastfeed without being noticed if you sit in a booth, or near a tall plant or choose a corner table and sit with your back to the room. ${ }^{133}$ Discretion disguises not only the breast itself but the fact of what it is that a breastfeeding woman is doing. This suggests that offence and disgust caused by breastfeeding extends beyond the possibility of seeing bare breast, the nipple or the areola. It is the act of breastfeeding, the excretion and taking up of breast milk that must be hidden. ${ }^{134}$ There is an implicit understanding that the 'right' to supply nutrients to an infant under the Amendment is limited to the right to do so discreetly. The need to be invisible by hiding in a booth or ducking behind a plant shows how in breastfeeding '[w]omen's body language speaks eloquently, though silently, of her subordinate status. ${ }^{, 135}$

\section{Conclusion}

The Amendment intends to remove social constraints upon breastfeeding as a way to encourage extended breastfeeding practices. This legislative change has given breastfeeding women lawful redress to discrimination, but the discourse surrounding its introduction suggests that it was concerned with ensuring access to the health benefits of breast milk not with protecting the act of breastfeeding per se. So long as the rationale for the legislation remains couched within this public health discourse the intention of the Amendment is vulnerable to challenge. The legitimising arguments that framed the introduction of the Amendment needed to acknowledge breastfeeding as an in-principle women's right if it was to make a sincere attempt at erasing current social pressures that curtail public breastfeeding. The Amendment is otherwise situated within a framework

\footnotetext{
133 http://www. breastfeeding.asn.au/bfinfo/out.html

134 Chatard Carpenter above n 11.352; Giles above n 13.

${ }^{135}$ Barky (1998) in Stearns above n 11, 322.

Public Space: The Journal of Law and Social Justice (2008) Vol 2, Art 5 pp 1-29.
} 
that denies the difference of the female reproductive body and allows for the ongoing diminishment of women's breastfeeding experience.

\section{Bibliography}

\section{Articles}

Bartlett A (2002) 'Scandalous Practices and Political Performances: breastfeeding in the city' Continuum: Journal of Media and Cultural Studies, Vol.16, No.1, 2002.

Bartlett A (2003) 'Breastfeeding Bodies and Choice in Late Capitalism' Hecate, On line publication, $1^{\text {st }}$ October 2003.

Bartlett A and Giles F (2004) 'Theme: meanings of breastmilk: new feminist flavours: Introduction: taking our breasts to work' Australian Feminist Studies, Vol.19, No.45, November 2004 pp. $269-271$

Blum L (1993) 'Mothers, Babies and Breastfeeding in Late Capitalist America: The Shifting Contexts of Feminist Theory' Feminist Studies, Col.19, No.2, pp290 - 312

Cain PA (1990) 'Feminism and the Limits of Equality' in Freeman M.D.A Lloyds Introduction to Jurisprudence, Seventh Edition, Thompson, London 2001 pp.1149 - 1157

Casas N (2001) 'Sex Discrimination on the Basis of Pregnancy: Australia's Report on Pregnancy Discrimination Should Make the United States Re-evaluate the Effectiveness of the Pregnancy Discrimination Act in Eliminating Pregnancy Discrimination in the Workplace' Transnational Law and Contemporary Problems, pp141 - 174

Chatard Carpenter F (2006) ‘(L)activists and Latté's: Breastfeeding Advocacy as Domestic Performance' Women and Performance: a journal of feminist theory, Col.16, No.3, November 2006, pp.347-367

Giles F (2004) 'Relational and Strange: a preliminary foray into a project to queer breastfeeding' Australian Feminist Studies, Vol.19, No.45, November, pp.301-314

Hausman B (2004) 'The Feminist Politics of Breastfeeding' Australian Feminist Studies, Vol.19, No.45, November 2004 pp.273 - 285

Kevin C (2005) 'Maternity and Freedom: Australian Feminist Encounters with the Reproductive Body' Australian Feminist Studies, Vol.20, No.46, March 2005 pp.3-15

Mason G and Chapman A (2003) 'Defining Sexual Harassment: A History of the Commonwealth Legislation and its Critiques' Federal Law Review, Vol.31, pp.195 - 224 
MacKinnon CA (1987) 'Difference and Domination: On Sex Discrimination' in Freeman M.D.A Lloyds Introduction to Jurisprudence, Seventh Edition, Thompson, London 2001, pp $1175-1184$

Olson SI (1996) 'Out of the Mouths of Babes: No Mother's Milk for U.S. Children: The Law and Breastfeeding’ Hamline Law Review, Vol.19, pp.269 - 310

Rogers N (1994) 'Stepping out of the ivory tower with contemptuous breasts' Alternative Law Journal, Vol.19, No.3, June 1994 pp.115 - 117

Rogers N (1995) 'Wimmenspeak on Midwifery Lore' Murdoch University Electronic Journal of Law, Vol.2, No.3, December 1995.

Shaw R (2004) 'The Virtues of Cross-nursing and the 'Yuk Factor' Australian Feminist Studies, Vol.19, No.45, November 2004, pp287-299

Shelton DM (1996) 'When Private Goes Public: Legal Protection for Women who Breastfeed in Public and at Work' Law and Inequality, Vol.14, pp.179 - 202

Silberstein Shdaimah C (1999) 'Why Breastfeeding is (Also) a Legal Issue' Hastings Women's Law Journal, Vol.10, No.2, pp.409 - 443

Spencer B (2004) 'The milk of human-kindness: from a short (personal) history of the bra and its contents' Australian Feminist Studies, Vol.19, No.45, November 2004 pp.315 327

Stearns CA (1999) 'Breastfeeding and the Good Maternal Body' Gender and Society, Vol. 13, no. 3 (June 1999), pp.308-325

West R (1988) 'Jurisprudence and Gender' in Freeman M.D.A Lloyds Introduction to Jurisprudence, Seventh Edition, Thompson, London 2001 pp.1157 - 1175

\section{Texts}

Bartlett A Breastwork: Rethinking Breastfeeding, University of NSW Press Limited, 2005.

Baumslag N and Michels D Milk, Money and Madness: The Culture and Politics of Breastfeeding, Bergin and Garvey, USA, 1995.

Carter P Feminism, Breasts and Breastfeeding, McMillian Press, London, 1995.

Dettwyler KA 'Beauty and the Breast: The Cultural Context of Breastfeeding in the United States' Chapter 7 in Stuart-Macadam P and Dettwyler KA (eds) Breastfeeding Biocultural Perspectives Aldine De Gruyter, New York 1995.

Public Space: The Journal of Law and Social Justice (2008) Vol 2, Art 5 pp 1-29. 
Freeman M.D.A Lloyds Introduction to Jurisprudence, Seventh Edition, Thompson, London 2001.

Hausman BL 'Mothers Milk: Breastfeeding Controversies in American Culture' Routledge, New York 2003.

Heywood A Politics MacMillan Press, London, 1997.

Locke J 'the Second Treatise of Government' in Locke J. Two Treatise of Government, Everyman, London \& Vermont, 1997 ed, pp 115-222

Nussbaum M Hiding from Humanity: Disgust, Shame and the Law, Chapter 2, 'Disgust and our Animal Bodies', Princeton University Press, New Jersey, 2004.

Reiger KM Our Bodies, Our Babies: The Forgotten Women's Movement, Melbourne University Press, 2001.

Van Esterik P 'The Politics of Breastfeeding: An Advocacy Perspective' Chapter 6 in Stuart-Macadam P and Dettwyler KA (eds) Breastfeeding Biocultural Perspectives Aldine De Gruyter, New York 1995.

Young IM On Female Body Experience: 'Throwing Like a Girl' and Other Essays, New York, Oxford University Press, 2005 (downloaded from www.oxfordscholarship.com)

\section{Newspaper Articles}

The Australian (2007) 'Breastfeeding worsens asthma, allergies in children' The Australian, May $1^{\text {st }}, 2007$.

Ife, H (2007) 'Breastfeeding may pass on allergies' Herald Sun, October $1^{\text {st }}, 2007$.

Robins, B (2007) 'Law boosts public breastfeeding rights' Sydney Morning Herald, September 4, 2007, p.5

\section{Speeches}

Watchirs, Dr H and Earl J (2006) 'The relevance of a human rights framework in building a breastfeeding friendly culture in Australia' Australian Lactation Consultants Association International Conference, 27 October 2006.

\section{Media Releases}

Australian Breastfeeding Association (2007) 'Breastfeeding and Allergy Study Flawed' Media Release, 2 October, 2007.

Public Space: The Journal of Law and Social Justice (2008) Vol 2, Art 5 pp 1-29. 
Matheson M (2007) 'Breastfeeding increases long term allergy risks in those with a family history, says University of Melbourne study' University of Melbourne, Media Release, Monday $1^{\text {st }}$ October, 2007.

McIntyre E (1998) 'Community prefers bottle feeding to breastfeeding in public' The University of Adelaide, Media Release, Monday $6^{\text {th }}$ July 1998.

\section{Other}

Australian Bureau of Statistics (2001) 'Breastfeeding in Australia' 4810.0.55.001, Australia, 2001.

Collier B (2007) 'Anti-Discrimination Amendment (Breastfeeding Bill) 2007, Motion, Agreement in Principle, NSW Hansard Transcripts, Item 3 of 51, 26 September, 2007.

Commonwealth Hansard, Debate Sex Discrimination Amendment (Pregnancy and Work) Bill 2002, Second Reading, Monday $8^{\text {th }}$ September, 2003, $14349-14370$

HREOC (1999) 'Pregnant and Productive: It's a right not a privilege to work while pregnant', Sex Discrimination Unit, Human Rights and Equal Opportunity Commission, 1999.

Innocenti Declaration (1990) 'On the Protection, Promotion and Support of Breastfeeding' WHO/UNICEF, Florence, Italy, 1 August 1990.

Legislation Review Digest, No 3, Legislation Review Committee, NSW Parliament, 12 October, 2007.

New South Wales Department of Health (2006) 'Having a Baby' NSW Health, NSW Government, Families First, Sydney, 2006.

NSW Hansard, Debate Anti-Discrimination (Breastfeeding) Amendment Bill 2007, Second Reading, October $24^{\text {th }} 2007$. 